\title{
Polar-Organic-Chemical-Integrative Sampler (POCIS) uptake rates for 17 polar pesticides and degradation products: laboratory calibration
}

Imtiaz Ibrahim $^{\mathrm{a}, \mathrm{b}}$, Anne Togola ${ }^{\mathrm{a}}$, Catherine Gonzalez ${ }^{\mathrm{b}}$

Authors

I.Ibrahim

${ }^{a}$ Bureau de recherche géologiques et minières (BRGM), Laboratory Division, 3 avenue Claude Guillemin, 45100 Orléans, France

${ }^{b}$ Ecole des mines d'Alès (EMA), LGEI Center, 6 Avenue de Clavieres, 30319 Alès, France i.imtiaz@mines-ales.fr

Tel: (+33)4.66.78.27.22; Fax: (+33)4.66.78.27.01

\section{A.Togola}

${ }^{a}$ Bureau de recherche géologiques et minières (BRGM), Laboratory Division, 3 avenue Claude Guillemin, 45100 Orléans, France

a.togola@brgm.fr

Tel: (+33)2.38.64.38.36 ; Fax: (+33)2.38.64.39.25.

C. Gonzalez

${ }^{b}$ Ecole des mines d'Alès (EMA), LGEI Center, 6 Avenue de Clavieres, 30319 Alès, France catherine.gonzalez@mines-ales.fr

Tel: (+33)4.66.78.27.65; Fax: (+33)4.66.78.27.01 


\section{Abstract}

Polar organic chemical integrative samplers (POCIS) are useful for monitoring a wide range of chemicals, including polar pesticides, in water bodies. However, few calibration data are available, which limits the use of these samplers for time-weighted average concentration measurements in an aquatic medium. This work deals with the laboratory calibration of the pharmaceutical configuration of a polar organic chemical-integrative sampler (pharm-POCIS) for calculating the sampling rates of 17 polar pesticides $\left(1.15 \leq \log \mathrm{K}_{\mathrm{ow}} \leq 3.71\right)$ commonly found in water. The experiment, conducted for 21 days in a continuous water flow-through exposure system, showed an integrative accumulation of all studied pesticides for 15 days. 3 compounds (metalaxyl, azoxystrobine and terbuthylazine) remained integrative for the 21-day experiment. The sampling rates measured ranged from 67.9 to $279 \mathrm{~mL}$ day $^{-1}$ and increased with the hydrophobicity of the pesticides until reaching a plateau where no significant variation in sampling rate is observed when increasing the hydrophobicity.

Keywords: laboratory calibration, passive sampling, POCIS, polar pesticides

Abbreviations

\begin{tabular}{l|l} 
Polar organic chemical integrative sampler & POCIS \\
Pharmaceutical polar organic integrative sampler & Pharm-POCIS \\
Pesticide polar organic chemical integrative & Pest-POCIS \\
sampler & TWA \\
Time weighted average & DEA \\
Desethylatrazine & DIA \\
Desisopropylatrazine & DET \\
Desethylterbuthylazine & SPE \\
Solid phase extraction & PES \\
Polyethersulfone & UPLC \\
Ultra performance liquid chromatography & RSD \\
Relative standard deviation & MRM \\
Reaction monitoring mode &
\end{tabular}




\section{Introduction}

Over the past decades, many organic contaminants have been found in different aquatic environments. Among these pollutants, pesticides are mainly derived from agricultural activities (Schwarzenbach et al. 2006). Runoff over fields and infiltration caused by precipitation are the major causes of the presence of these agrochemicals in surface- and ground waters (Beltran et al. 1993). Pesticide pollution can be not only problematic for human health, considering drinking water, but also for aquatic organisms.

Continuous monitoring of pesticide concentrations in aquatic environments is necessary for assessing the water quality (Liess et al. 1999), whereby sampling is a crucial step. The conventional methods of screening for aquatic pollutants rely on the analysis of grab samples, but these techniques generally do not provide appropriate information on variability of micro-pollutants concentration in water. Spot sampling provides only a snapshot of pollutant concentrations at the time of sampling and is often insufficient for detecting and quantifying trace levels of contaminants in water. In addition, the concentration of pollutants can fluctuate depending on environmental conditions, and frequent sampling is required to monitor contaminant levels. However, increasing the sampling frequency means taking a larger number of water samples, which is time consuming, laborious and expensive.

In environmental analysis, the development and application of monitoring techniques based on passive sampling offer a new and alternative approach to monitoring programmes that rely on collecting spot samples. Passive sampling, in contrast to spot sampling, enables determination of the time-weighted average (TWA) concentration of water contaminants over long sampling periods, permits the detection of trace and ultra-trace contaminants by the in-situ pre-concentration of pollutants, and finally offers significant handling, use and economic benefits compared with conventional grab-sampling techniques (Kot et al. 2000).

Various types of samplers exist with different design characteristics for the sampling of aquatic organic pollutants of different polarities. Among the passive samplers available, the most widely used for sampling polar organic pollutants are the Chemcatchers ${ }^{\circledR}$ (Kingston et al. 2000, Greenwood et al. 2007, Vrana et al. 2007) and polar organic chemical integrative samplers (POCIS). POCIS consists of a solid sequestration phase (sorbent) enclosed between two hydrophilic microporous polyethersulfone (PES) membranes (porosity $0.1 \mu \mathrm{m}$ ). The surface area of POCIS is $41 \mathrm{~cm}^{2}$, and two configurations are commercially available: pharmaceutical-POCIS (pharm-POCIS) and pesticide-POCIS (pest-POCIS) (Alvarez et al. 2004).

The sorbent in POCIS samplers is usually based on polystyrene divinylbenzene combined with active carbon in the case of pest-POCIS, or Oasis ${ }^{\mathrm{TM}}$ HLB sorbent in pharm-POCIS. This sampler can retain a large range of polar organic pollutants from different classes of organic compounds, such as pesticides, non-ionic detergents, polar pharmaceuticals, or natural and synthetic hormones (Alvarez et al. 2004; 
MacLeod et al. 2007; Li et al. 2011; Pesce et al. 2011). Alvarez et al. (2004) reported that pharm-POCIS is more suitable for organic polar compounds with multiple functional groups, and Mazzella et al. (2007) mentioned that it is more convenient for the sampling of basic and neutral herbicides. There are some practical advantages in using pharm-POCIS for monitoring polar organic contaminants, including the use of less solvents than for recovering analytes from pest-POCIS (Li et al. 2011).

A detailed description of these tools and their respective applications is available in the literature (Alvarez 1999; Alvarez et al. 2004; Petty et al. 2004; MacLeod et al. 2007; Mazzella et al. 2007; Arditsoglou and Voutsa 2008; Li et al. 2011; Pesce et al. 2011).

The POCIS approach has been used as a screening tool for determining the presence of possible sources and relative amounts of organic contaminants in surface water and wastewater This approach allows the detection of new compounds such as pharmaceuticals, detergent identified as "emerging pollutants", that cannot be detected by spot sampling, (Petty et al. 2004).

However, the use of POCIS as a quantitative tool for determining TWA concentrations requires calibration studies for the estimation of sampling rates of the targeted compounds. To date, POCIS sampling rates have been determined for only few pesticides (Mazzella et al. 2007; Togola and Budzinski 2007; Arditsoglou and Voutsa 2008; Li et al. 2011). The theory of passive sampling was described earlier as well (Alvarez et al. 2004; Mazzella et al. 2007; Togola and Budzinski 2007).

The objective of this study was to determine the sampling rates of 17 polar pesticides (Table 1) by pharmPOCIS in a laboratory-calibration experiment, in order to use this sampler as a quantitative tool for TWA concentration measurements in different aquatic environments. The studied compounds were atrazine, simazine, desethylatrazine (DEA), desisopropylatrazine (DIA), desethylterbuthylazine (DET), terbuthylatrazine, diuron, isoproturon, chlortoluron, linuron, propyzamide, alachlor, metolachlor, acetochlor, metalaxyl, penconazole and azoxystrobine.

\section{Material and methods}

\section{Chemicals and materials}

All pesticides analytical standards (purity $>98 \%$ ) were provided by Dr. Ehrenstorfer (CIL, Sainte Foy La Grande, France). Individual solutions of pesticides $\left(500 \mathrm{mg} \mathrm{L}^{-1}\right)$ were prepared in acetonitrile and stored in the dark at $-18^{\circ} \mathrm{C}$. Standard working mixtures of pesticides $\left(3 \mathrm{mg} \mathrm{L}^{-1}\right)$ prepared in acetonitrile were used for the experiment. Deuterated labelled compounds, simazine-d10 (98\%) and atrazine-d5 (97.5\%) were obtained from Dr. Ehrenstorfer (see above) and were used for recovery control and analytical control, respectively. Acetonitrile and methanol (HPLC grade) were obtained from Fisher Chemical (Illkirch, France) and formic acid was from Avantor (Deventer, the Netherlands). Water used for experimental processes was generated by a Millipore direct-ultrapure water system with a specific 
resistance of $18.2 \mathrm{M} \Omega \mathrm{cm}^{-1}$. Oasis ${ }^{\mathrm{TM}} \mathrm{HLB}$ extraction cartridges $(500 \mathrm{mg}, 60 \mu \mathrm{m})$ were purchased from Waters Corporation (Guyancourt, France). Exposmeter SA (Tavelsjö, Sweden) provided the pharmaceutical POCIS samplers. Empty polypropylene solid-phase extraction (SPE) tubes with polyethylene frits were purchased from Supelco (Saint-Quentin Fallavier, France). An HPLC pump (ProStar 220, Varian, Les Ulis, France) and a peristaltic pump (Labcraft) were used in the experimental set-up for supplying water. An Autotrace SPE workstation (Caliper Life Sciences, Villepinte, France) was used for the water-sample processing and a Visiprep SPE Manifold (Supelco) was used for POCIS processing.

\section{Experiment design}

The POCIS calibration experiment was conducted in a $100 \mathrm{~L}$ stainless steel tank filled with tap water $(\mathrm{pH}$ $=8.3$ ) initially fortified at $1.1 \mu \mathrm{g} \mathrm{L}^{-1}$ of each target pesticide. The tank was designed to contain an inert Teflon carrousel, connected to an electric motor with an adjustable rotation speed for simulating turbulent conditions in water. For determining the sampling rates, 12 pharm-POCIS were initially immersed in the tank, attached to the carrousel. To study the kinetic accumulation of pesticides in the POCIS, the samplers were successively removed from the tank in triplicate at set time intervals (5, 9, 15 and 21 days) and analysed to determine the amount of accumulated chemicals. In order to maintain the concentration of pesticides in water constant, the tank was continuously supplied with tap water spiked with pesticides at $1.1 \mu \mathrm{g} \mathrm{L}^{-1}$ with flow rate of $7 \mathrm{~mL} \mathrm{~min}{ }^{-1}$. The volume of methanol added in the tank for the initial supplementation was very low (less than $0.03 \%$ of the total volume) and the volume of methanol added all along the experiment was estimated to $0.004 \%$ and doesn't change significantly the DOC value. The monitoring of pesticide concentrations in the tank during the experiment was done by sampling $200 \mathrm{~mL}$ of water in triplicate from the outlet of the tank at each time the POCIS were removed. The water temperature and $\mathrm{pH}$ in the tank were monitored during the experimental period and remained stable with a mean of $21^{\circ} \mathrm{C}$ (from $20.8^{\circ} \mathrm{C}$ to $21.5^{\circ} \mathrm{C}$ ) for temperature and from 8.2 to 8.4 with a mean of 8.3 for $\mathrm{pH}$. The carrousel rotation speed was fixed at $10 \mathrm{rpm}\left(0.115 \mathrm{~m} \mathrm{~s}^{-1}\right)$. Blank POCIS have been deployed during exposure in parallel, showing no contamination by targeted compounds during the experiment.

\section{Sample treatment}

After exposure, each POCIS was opened and the sorbent was recovered from the PES membranes with ultrapure water and transferred into a $1 \mathrm{~mL}$ empty SPE tube with a polyethylene frit and packed under vacuum by using the Visiprep SPE manifold. The sorbent was dried for $30 \mathrm{~min}$ under vacuum. Prior to extraction, $75 \mu \mathrm{L}$ of atrazin- $\mathrm{d} 5\left(0.5 \mathrm{mg} \mathrm{L}^{-1}\right)$ was added during the sequestering phase. Pesticides were extracted by eluting under vacuum with $10 \mathrm{~mL}$ of acetonitrile. The eluate was evaporated under a gentle stream of nitrogen and the volume of the extract was reduced to $1 \mathrm{~mL}$. After elution, the sorbent was dried at $40^{\circ} \mathrm{C}$ and weighted. All results were corrected by using the real mass of sorbent in each exposed sampler. 
Water samples $(200 \mathrm{~mL})$ were extracted via SPE using the autotrace SPE workstation. The HLB cartridges were successively pre-conditioned with $5 \mathrm{~mL}$ acetonitrile, $5 \mathrm{~mL}$ methanol and then $5 \mathrm{~mL}$ of ultrapure water at $5 \mathrm{ml} \mathrm{min}^{-1}$. Prior to extraction, each sample was fortified with $125 \mathrm{ng}$ of atrazine-d5. The samples were passed through the cartridges under vacuum at a flow rate of $10 \mathrm{ml} \mathrm{min}^{-1}$. Before elution, the cartridges were dried under vacuum for $1 \mathrm{~h}$. Analytes were recovered by eluting the cartridges with $8 \mathrm{~mL}$ of acetonitrile at a flow rate of $3 \mathrm{~mL} \mathrm{~min}^{-1}$. The sample volume was reduced to $1.5 \mathrm{~mL}$ under a gentle stream of nitrogen and transferred to an autosampler vial.

All sample extracts were spiked before analysis with $50 \mu \mathrm{L}$ of the deuterated internal standard simazine$\mathrm{d} 10\left(2 \mathrm{mg} \mathrm{L}^{-1}\right)$.

\section{Pesticide analyses}

All POCIS and cartridges extracts were analysed by UPLC-MS/MS. Liquid chromatography separations were done in a Waters ACQUITY UPLC system (Waters, Guyancourt, France) using a $150 \mathrm{~mm} \times 2.1 \mathrm{~mm}$ $\times 1.7 \mu \mathrm{m}$ ACQUITY BEH C18 column. The mobile phase was composed of solvent A $(0.05 \%$ formic acid in water) and solvent $\mathrm{B}\left(0.05 \%\right.$ formic acid in acetonitrile) at a constant flow of $0.4 \mathrm{~mL} \mathrm{~min}^{-1}$. The gradient was programmed to increase the amount of B from $0 \%$ to $100 \%$ in $7.5 \mathrm{~min}$, with stabilization at $100 \%$ for $1.5 \mathrm{~min}$ before returning to the initial conditions $(0 \% \mathrm{~B})$ in $0.3 \mathrm{~min}$. These conditions were maintained for $15 \mathrm{~min}$. Mass spectrometry detection was done with a Quattro Premier XE MS/MS (Waters, Guyancourt, France) fitted with an ESI interface and controlled by MassLynx software. Typical interface conditions were optimized for maximum intensity of the precursor ions as follows: nebulizer and desolvation (drying gas, $\mathrm{N}_{2}$ ) flows were set at 650 and $150 \mathrm{~L} \mathrm{~h}^{-1}$, respectively; source block and desolvation temperatures were 100 and $350^{\circ} \mathrm{C}$, respectively. The ESI polarity ionization mode was set individually for each target compound. Argon was used as collision gas at a pressure of $3.7 \times 10^{-3} \mathrm{mBar}$. Mass spectra were performed in the multiple reaction-monitoring mode (MRM). The mass-spectrum acquisition of each compound was done by recording two characteristic fragments: a transition one was used for quantitation and the other for confirmation.

\section{Stability of pesticides in the aqueous phase}

During the 21 days of the experiment, the aqueous concentration of pesticides in the tank was monitored at each time the POCIS were removed. If concentrations are kept relatively constant during laboratory calibration, the sampling rate for each pesticide can be calculated when accumulation in the sampler follows a linear pattern. The results showed a relatively constant chemical concentration (R.S.D = 3$12 \%$ ) in the exposure tank throughout the experiment, with average concentrations ranging from $568 \mathrm{ng}$ $\mathrm{L}^{-1}$ (penconazole) to $1337 \mathrm{ng} \mathrm{L}^{-1}$ (DIA) (Table 2). Average concentrations presented in table 2 concern 
mean values calculated from water sampled in triplicate at the $5^{\text {th }}, 9^{\text {th }}$ and $15^{\text {th }}$ day of exposure $(9$ water samples) and used for calculations.

\section{Sampling rate calculation}

Accumulation of contaminants by passive samplers typically follows first-order kinetics, which includes an initial integrative phase, followed by curvilinear and equilibrium-partitioning phases. POCIS requires a relatively long sampling time before reaching equilibrium, and accumulation thus tends to remain for a long period after deployment in the integrative phase when analyte uptake is linear. In the linear region of POCIS uptake, the amount of a chemical accumulated in the sampler (M) is described by equation (1):

$$
M=C w R s t
$$

where $\mathrm{R}_{\mathrm{S}}$ is the sampling rate $\left(\mathrm{L} \mathrm{day}{ }^{-1}\right), \mathrm{CW}$ is the concentration of the compound in water $\left(\mathrm{ng} \mathrm{L}^{-1}\right)$ and $t$ the exposure time (day).

The experimental data obtained from the laboratory calibration tests were used for calculating the sampling rates $\left(R_{s}\right)$ of the target pesticides according to equation (1). To simplify the calculation of $R_{s}$, the regression line for each pesticide was fitted through the origin. A linear regression model with zero intercept was also used in other studies (Mazzella et al. 2007; Arditsoglou and Voutsa 2008; Martínez Bueno et al. 2009). For each pesticide, the sampling rate was determined by dividing the slope of the linear regression curve by the mean aqueous concentration for the selected compounds during the first 15days exposure.

The sampling rate of each compound was calculated by dividing the slope of the uptake curve plotted for 15 days exposure by the mean aqueous concentration of the corresponding compound computed for the similar exposure time, which corresponds to an average of 9 water samples. As the experience of analytes uptake by POCIS has been done in triplicate, the mean and standard deviation of $\mathrm{R}_{\mathrm{s}}$ for each compound was calculated by taking in account the values obtained for the POCIS in triplicate.

\section{Results and discussion}

\section{Pesticide uptake kinetics by POCIS}

Characteristic pesticide uptake curves for the pharm-POCIS after an exposure of 5, 9, 15 and 21 days in the spiked tap water under water flow over the POCIS conditions are shown in figure 1. The results showed that for most of the studied compounds, the uptake in POCIS follows a linear pattern until 15 days with an equilibrium state reached after a 21-day exposure. However, for three compounds (metalaxyl, azoxystrobine, terbuthylazine), the accumulation in POCIS remained linear for the whole 21day experiment. 


\section{Determining sampling rates}

The correlation coefficients of the linear regressions for most pesticides were acceptable, with values from 0.7924 (DEA) to 0.9706 (azoxystrobine) (Table 3). Pesticide sampling rates expressed in $\mathrm{mL} \mathrm{g}^{-1} \mathrm{~d}^{-1}$ and $\mathrm{mL} \mathrm{day}^{-1}$ (computed for $200 \mathrm{mg}$ of HLB sorbent phase) are given in Table 3 . The calculated $\mathrm{R}_{\mathrm{s}}$ values ranged from 67.9 to $279 \mathrm{~mL}$ day $^{-1}$ with $\mathrm{RSD} \leq 17 \%$. The lowest sampling rate value was obtained for the most polar compound DIA $\left(\log \mathrm{K}_{\mathrm{ow}}=1.2\right)$, demonstrating that POCIS is less effective for sequestering this molecule. A similar result was observed by Mazzella et al. (2007) when calibrating pharm-POCIS in the laboratory. Penconazole showed the highest $\mathrm{R}_{\mathrm{s}}$ value $\left(279 \mathrm{~mL} \mathrm{day}^{-1}\right)$.

\section{Comparison of sampling rates}

An overview of our sampling rates and those of previous studies is given in Table 4 concerning only experiments fitting with our own experiment in term of exposure conditions (water renewal and nonquiescent exposure). For several pesticides, the sampling-rate values from our study were similar to those obtained by authors (Mazzella et al. 2007; Hernando et al. 2007; Lissalde et al. 2011) who used a similar experimental set-up for pharm-POCIS calibration as ours. The $\mathrm{R}_{\mathrm{s}}$ values we obtained for terbuthylazine and linuron were 1.5 and 1.7 times lower, respectively, than those reported by Mazzella et al. (2007) and Lissalde et al. (2011) even if the results for the other compounds are very closed. This difference cannot be explained and those both results seem to be not reliable because of the important difference of sampling rate compared to the other compounds owning to the same chemical group (140 $\mathrm{ml}$ day for linuron instead of respectively 256.7 and 236.5 for diuron and isoproturon). Our sampling rates were of the same order of magnitude as those obtained by Thomatou et al. (2011), even though these authors used a pest-POCIS in a stirred-renewal exposure design for a calibration experiment using natural lake water. Sampling-rate values for diuron from other studies were systematically below our values: 3 times lower for Martínez Bueno et al. (2009) and 5.7 times lower for Alvarez et al. (2004), respectively. The experimental set-ups used by these authors use a static system stirred by a magnetic bar, but their salinity values were quite different.

It is thus clear that great disparities exist between the methods used for calibrating POCIS. Detailed descriptions of experimental parameters and $\mathrm{R}_{\mathrm{s}}$ comparisons during POCIS calibrations for several pesticides and other chemicals are given by Munaron et al. (2011) and Morin et al. (2012). For the pesticides, $R_{\mathrm{s}}$ values are comparable to the present study and the observed differences can be explained by considering the different parameters, such as the experimental set-up for calibration (such as water renewal..), water-temperature and turbulence conditions that affect the sampling rate, the POCIS configuration and the value of its surface area - sorbent-phase ratio. Large differences between the experimental conditions used may lead to large variations in $R_{s}$ values. As described by Morin et al. (2012), there is a lot of studies in which all the needed information (speed of rotation, water temperature, calibration methods...) are not clearly expressed. These discrepancies highlight the need for standardized 
POCIS manufacture and calibration procedures in order to compare and use $\mathrm{R}_{\mathrm{s}}$ data obtained in the different studies. A first EN-ISO document (EN-ISO 2011) is already available, but this document gives a general guidance and could not constitute a basis for use as a standard. It should be implemented by definitions of exposure conditions that need to be respected or explicated to enhance reliability of obtained data.

\section{Relationship between sampling rates and physical-chemical properties}

A non-linear regression was performed for sampling rates determined from the calibration experiments, using a second-order polynomial function of $\log \mathrm{K}_{\mathrm{ow}}\left(\mathrm{Y}=-44.701 \mathrm{X}^{2}+289.14 \mathrm{X}-199.69 ; \mathrm{r}^{2}=0.9221\right)$ (Fig. 2). To obtain a better correlation, the $\mathrm{R}_{\mathrm{s}}$ values of metalaxyl, propyzamide and azoxystrobine were not plotted, even though their mean $R_{\mathrm{s}}$ values are included in the graph. The quadratic curve shows an increase of the sampling rates with the hydrophobicity $\left(\log \mathrm{K}_{\mathrm{ow}}\right)$, reaching a plateau for compounds with $\log \mathrm{K}_{\mathrm{ow}}$ ranging from 1.15 to 3.7. Mazzella et al. (2007) and Thomatou et al. (2011) when calibrating POCIS for polar pesticides established a similar relationship. Arditsoglou and Voutsa (2008) when working with steroid and phenolic compounds found no clear correlation, but they showed a similarity in sampling-rate values across a range of hydrophobic molecules. The observed plateau from our study, which describes a similarity of POCIS uptake over a range of hydrophobicity $\left(\log \mathrm{K}_{\mathrm{ow}}: 1.7-3.7\right)$, was also reported for pesticides on polar Chemcatchers ${ }^{\circledR}$ (Shaw et al. 2009) for the uptake by the RPS-SDB sorbent phase for the compounds studied ( $\left.\log \mathrm{K}_{\text {ow }}: 1.78-4.0\right)$. According to Alvarez et al. (2007b), POCIS are able to accumulate compounds with $\log \mathrm{K}_{\mathrm{ow}}<3$. The selected pesticides in this work have $\log \mathrm{K}_{\mathrm{ow}}$ values that range from 1.15 (DIA) to 3.72 (penconazole). For all compounds studied except DIA, we obtained sampling rates of over $100 \mathrm{~mL}$ day $^{-1}$. The sampling rates generated by Arditsoglou and Voutsa (2008) when working with steroid and phenolic compounds ( $\left.\log \mathrm{K}_{\mathrm{ow}}: 2.81-4.67\right)$ ranged from 90 to $221 \mathrm{~mL}^{\text {day }}{ }^{-1}$; their experimental data suggest that POCIS can be used even with compounds whose $\log \mathrm{K}_{\text {ow }}$ is over 4 . The limits of POCIS performance and sampling efficiency should be defined by considering compounds from the same chemical groups. Fig. 3 focuses on the range of compound sampling rates on the plateau of the curve described above (Fig. 2). The mean sampling rate calculated for the 13 compounds is $239 \mathrm{~mL}$ day $^{-1}$ with a relative standard deviation of $14 \%$. Considering that the determination of average concentrations by passive sampling with an RSD of $20 \%$ in environmental measurements is acceptable, the main idea could be to use a unique sampling rate value for calculating the TWA concentration of any pesticide in the aquatic environment whose polarity falls in the $\log \mathrm{K}_{\mathrm{ow}}$ interval determined above. In order to further develop this point, other experiments are needed with a large number of compounds belonging to different chemical classes and with a wide range of polarity values. $R_{s}$ variability for molecules falling in the proposed $\log \mathrm{K}_{\mathrm{ow}}$ interval is much lower than the $\mathrm{R}_{\mathrm{s}}$ variability for various conditions of temperature and agitation. The demonstration is highlighted by the result presented in figure 3. It is also possible to consider an "average global" $\mathrm{R}_{\mathrm{s}}$ for all compound owning to the $\log \mathrm{K}_{\text {ow }}$ intervals 
and to focus the research on developing correction of lab- $\mathrm{R}_{\mathrm{s}}$ to fit with environmental conditions. Different ways could be investigated: use of PRC compounds (Mazzella 2007), use of passive flow monitor (O Brien, 2012) already applied for SPMD (semipermeable membrane device) and PDMS (polydimethyl siloxan) passive samplers and which could be useful for POCIS. It will be more interesting to focus the research on developing correction of lab-Rs to fit with environmental conditions with a validation by in-situ calibrations.

\section{Conclusions}

The quantitative use of POCIS requires suitable sampling-rate values for each compound of interest. Very few sampling-rate data are available for estimating ambient contaminant concentrations from analyte levels in exposed POCIS.

A laboratory experiment based on a flow-through exposure system was designed and implemented for the calibration of POCIS (pharmaceutical configuration), and the sampling rates of 17 polar pesticides were determined. The calibration revealed integrative uptakes of the target pesticides for 15 and 21 days. The obtained sampling rates ranged from 67.9 to $279 \mathrm{~mL}$ day $^{-1}$ and demonstrated the effectiveness of POCIS for achieving a lower quantification limit for the selected compounds, compared to standard activesampling methods. For an exposure duration of 15 days, we have the equivalence of a 1 to $4 \mathrm{~L}$ grab water sample, depending on the targeted compounds.

The calibration results obtained showed a similar POCIS sampling capacity for several compounds belonging to different chemical classes, with a $\log \mathrm{K}_{\mathrm{ow}}$ ranging from 1.7 to 3.7. The use of an average laboratory- $\mathrm{R}_{\mathrm{s}}$ could be considered for determining the TWA concentration in water for a given compound, whose polarity falls within a defined interval with other compounds that have similar sampling-rate values. This Lab- $\mathrm{R}_{\mathrm{s}}$, need to be improved and corrected (by PRC or passive flow monitor) to fit better with realistic environmental conditions.

\section{Acknowledgements}

The authors would like to thank C. Coureau for her valuable assistance in laboratory analyses and M. Kleuvers for his precious help for the english text correction. We also thank the Carnot institute (BRGM) and the engineering school of Alès (EMA) for financial support of this study, which is a part of a $\mathrm{PhD}$ research. 


\section{References}

Alvarez DA (1999) Development of an integrative sampling device for hydrophilic organic contaminants in aquatic environments, Missouri-Columbia, Columbia, $160 \mathrm{pp}$

Alvarez DA, Petty JD, Huckins JN, Jones-Lepp TL, Getting DT, Goddard JP, Manahan SE (2004) Development of a passive, in situ, integrative sampler for hydrophilic organic contaminants in aquatic environments. Environ. Toxic. and Chem. 23:1640-1648

Alvarez DA, Huckins JN, Petty JD, Jones-Lepp T, Stuer-Lauridsen F, Getting DT, Goddard JP, Gravell A (2007a) Tool for monitoring hydrophilic contaminants in water: polar organic chemical integrative sampler (POCIS). In: Greenwood R, Mills GA, Vrana B (Editors), Comprehensive Analytical Chemistry. Passive Sampling Techniques in Environmental Monitoring. Elsevier, pp. 171-197

Alvarez DA, Huckins JN, Petty JD, Jones-Lepp T, Stuer-Lauridsen F, Getting DT, Goddard JP, Gravell A (2007b) Chapter 8 Tool for monitoring hydrophilic contaminants in water: polar organic chemical integrative sampler (POCIS). In:Greenwood R, Mills GA, Vrana B (Editors), Passive Sampling Techniques in Environmental Monitoring. Comprehensive Analytical Chemistry. Elsevier, pp. 171

Arditsoglou A, Voutsa D (2008) Passive sampling of selected endocrine disrupting compounds using polar organic chemical integrative samplers. Environ. Pollut. 156:316-324

Beltran J, Lopez FJ, Hernandez F (1993) Solid-phase extraction of pesticide residues from ground water: comparison between extraction cartridges and extraction discs. Anal. Chim. Acta 283:297-303

Greenwood R, Mills GA, Vrana B (2007) Passive sampling techniques in environmental monitoring. Comprehensive analytical chemistry. Elsevier

ISO 5667-23:2011 Water quality -- Sampling -- Part 23: Guidance on passive sampling in surface waters, $23 \mathrm{p}$

Kingston JK, Greenwood R, Mills GA, Morrison GM, Persson LB (2000) Development of a novel passive sampling system for the time-averaged measurement of a range of organic pollutants in aquatic environments. J. Environ. Monit. 2:487-495

Kot A, Zabiegała B, Namiesnik J (2000) Passive sampling for long-term monitoring of organic pollutants in water. Trend Anal Chem 19:446-459

Li H, Helm PA, Paterson G, Metcalfe CD (2011) The effects of dissolved organic matter and pH on sampling rates for polar organic chemical integrative samplers (POCIS). Chemosphere 83:271-280

Liess M, Schulz R, Liess MHD, Rother B, Kreuzig R (1999) Determination of insecticide contamination in agricultural headwater streams. Water Res. 33:239-247

Lissalde S, Mazzella N, Fauvelle V, Delmas François, Mazellier P, Legube B (2011) Liquid chromatography coupled with tandem mass spectrometry method for thirty-three pesticides in natural water and comparison of performance between classical solid phase extraction and passive sampling approaches. J Chromatogr. A 1218:1492-1502

Hernando M.D, Lambropoulou D, Konstantinou I, Bueno MMJ, Gabrielides D, Alba FAR, Albanis T (2007) Passive sampling techniques for monitoring organic contaminants in aquaculture environment. 
Proceedings of the 10th International Conference on Environmental Science and Technology, Kos Island, Greece, 5-7-September 2007.

MacLeod S, McClure E, Wong C (2007) Laboratory calibration and field deployment of the Polar Organic Chemical Integrative Sampler for pharmaceuticals and personal care products in wastewater and surface water. Environ. Toxicol. and Chem., pp. 2517-2529

Martínez Bueno MJ, Hernando MD, Agüera A, Fernández-Alba AR (2009) Application of passive sampling devices for screening of micro-pollutants in marine aquaculture using LC-MS/MS. Talanta $77: 1518-1527$

Mazzella N, Dubernet JF, Delmas F (2007) Determination of kinetic and equilibrium regimes in the operation of polar organic chemical integrative samplers: Application to the passive sampling of the polar herbicides in aquatic environments. J Chromatogr A 1154:42-51

Morin N, Miège Cécile, Coquery M, Randon Jérôme (2012) Chemical calibration, performance, validation and applications of the polar organic chemical integrative sampler (POCIS) in aquatic environments. Trend Anal Chem 36:144

Munaron D, Tapie N, Budzinski Hélène, Andral B, Gonzalez JL (2011) Pharmaceuticals, alkylphenols and pesticides in Mediterranean coastal waters: Results from a pilot survey using passive samplers. Estuar Coast Shelf S, doi 10.1016/j.ecss.2011.09.009 (in press)

O'Brien D, Komarova T, Mueller JF (2012) Determination of deployment specific chemical uptake rates for SPMD and PDMS using a passive flow monitor. Mar Pollut Bull. 64(5):10051011

Pesce S, Morin S, Lissalde S, Montuelle B, Mazzella N (2011) Combining polar organic chemical integrative samplers (POCIS) with toxicity testing to evaluate pesticide mixture effects on natural phototrophic biofilms. Environ. Pollut. 159:735-741

Petty JD, Huckins JN, Alvarez DA, Brumbaugh WG, Cranor WL, Gale RW, Rastall AC, Jones-Lepp T, Leiker TJ, Rostad CE, Furlong ET (2004) A holistic passive integrative sampling approach for assessing the presence and potential impacts of waterborne environmental contaminants. Chemosphere 54:695-705 Schwarzenbach RP, Escher BI, Fenner K, Hofstetter TB, Johnson CA, von Gunten U, Wehrli B (2006) The challenge of micropollutants in aquatic systems. Science 313:1072-1077

Shaw M, Eaglesham G, Mueller JF (2009) Uptake and release of polar compounds in SDB-RPS EmporeTM disks; implications for their use as passive samplers. Chemosphere 75:1-7

Thomatou AA, Zacharias I, Hela D, Konstantinou I (2011) Passive sampling of selected pesticides in aquatic environment using polar organic chemical integrative samplers. Environ. Sci. and Pollut. Res. 18, $1222-1233$

Togola A, Budzinski H (2007) Development of Polar Organic Compounds Integrative Samplers for analysis of pharmaceuticals in aquatic systems. Anal. Chem. 79:6734-6741 
Vrana B, Mills GA, Kotterman M, Leonards P, Booij K, Greenwood R (2007) Modelling and field application of the Chemcatcher passive sampler calibration data for the monitoring of hydrophobic organic pollutants in water. Environ. Pollut. 145-3:895-904 
Table 1 Physico-chemical properties of selected compounds

\begin{tabular}{|c|c|c|c|c|c|c|c|}
\hline Compound & Cas number & type & Chemical class & $\mathrm{Chemical}_{\text {formula }}$ & $\begin{array}{c}\text { MWeight } \\
(\mathrm{g} / \mathrm{mol})\end{array}$ & LogK & $\mathrm{pKa}$ \\
\hline Azoxystrobine & $131860-33-8$ & fungicide & strobilurine & $\mathrm{C}_{22} \mathrm{H}_{17} \mathrm{~N}_{3} \mathrm{O}_{5}$ & 403,4 & 2,5 & $\mathrm{nd}$ \\
\hline Metalaxyl & $57837-19-1$ & fungicide & amide & $\mathrm{C}_{15} \mathrm{H}_{21} \mathrm{NO}_{4}$ & 279,3 & 1,7 & nd \\
\hline Penconazole & $66246-88-6$ & fungicide & azole & $\mathrm{C}_{13} \mathrm{H}_{15} \mathrm{Cl}_{2} \mathrm{~N}_{3}$ & 284,2 & 3,7 & 1,5 \\
\hline Acetochlor & $34256-82-1$ & herbicide & chloracetanilide & $\mathrm{C}_{14} \mathrm{H}_{20} \mathrm{ClNO}_{2}$ & 269,8 & 3,0 & nd \\
\hline Alachlor & $15972-60-8$ & herbicide & chloracetanilide & $\mathrm{C}_{14} \mathrm{H}_{20} \mathrm{ClNO}_{2}$ & 269,8 & 3,5 & nd \\
\hline Atrazin & $1912-24-9$ & herbicide & triazine & $\mathrm{C}_{8} \mathrm{H}_{14} \mathrm{ClN}_{5}$ & 215,7 & 2,6 & 1,7 \\
\hline Chlortoluron & $15545-48-9$ & herbicide & urea & $\mathrm{C}_{10} \mathrm{H}_{13} \mathrm{ClN}_{2} \mathrm{O}$ & 212,7 & 2,4 & nd \\
\hline DEA & $6190-65-4$ & herbicide & triazine metabolite & $\mathrm{C}_{6} \mathrm{H}_{10} \mathrm{ClN}_{5}$ & 187,6 & 1,5 & nd \\
\hline DET & $30125-63-4$ & herbicide & triazine metabolite & $\mathrm{C}_{7} \mathrm{H}_{12} \mathrm{ClN}_{5}$ & 201,7 & 2,3 & nd \\
\hline DIA & $1007-28-9$ & herbicide & triazine metabolite & $\mathrm{C}_{5} \mathrm{H}_{8} \mathrm{ClN}_{5}$ & 173,6 & 1,2 & nd \\
\hline Diuron & $330-54-1$ & herbicide & urea & $\mathrm{C}_{9} \mathrm{H}_{10} \mathrm{Cl}_{2} \mathrm{~N}_{2} \mathrm{O}$ & 233,1 & 2,7 & nd \\
\hline Isoproturon & $34123-59-6$ & herbicide & urea & $\mathrm{C}_{12} \mathrm{H}_{18} \mathrm{~N}_{2} \mathrm{O}$ & 206,3 & 2,9 & nd \\
\hline Linuron & $330-55-2$ & herbicide & urea & $\mathrm{C}_{9} \mathrm{H}_{10} \mathrm{Cl}_{2} \mathrm{~N}_{2} \mathrm{O}_{2}$ & 249,1 & 3,2 & nd \\
\hline Metolachlor & $51218-45-2$ & herbicide & chloracetanilide & $\mathrm{C}_{15} \mathrm{H}_{22} \mathrm{ClNO}_{2}$ & 283,8 & 3,1 & nd \\
\hline Propyzamide & $23950-58-5$ & herbicide & amide & $\mathrm{C}_{12} \mathrm{H}_{11} \mathrm{Cl}_{2} \mathrm{NO}_{3}$ & 256,1 & 3,4 & nd \\
\hline Simazin & $122-34-9$ & herbicide & triazine & $\mathrm{C}_{7} \mathrm{H}_{12} \mathrm{ClN}_{5}$ & 201,7 & 2,2 & 1,6 \\
\hline terbuthylazin & $5915-41-3$ & herbicide & triazine & $\mathrm{C}_{9} \mathrm{H}_{16} \mathrm{ClN}_{5}$ & 229,7 & 3,2 & 2 \\
\hline
\end{tabular}


Table 2 Selected pesticides mean aqueous concentrations in the tank for 15 days experiment

\begin{tabular}{|c|c|c|}
\hline & $\begin{array}{c}\text { average } \\
\text { concentration } \\
(\mu \mathrm{g} / \mathrm{L})(\mathrm{n}=9)\end{array}$ & RSD (\%) \\
\hline acetochlor & 0,843 & $7 \%$ \\
\hline alachlor & 0,790 & $6 \%$ \\
\hline atrazin & 0,880 & $3 \%$ \\
\hline diuron & 0,890 & $12 \%$ \\
\hline linuron & 1,020 & $8 \%$ \\
\hline chlortoluron & 1,045 & $8 \%$ \\
\hline desethylatrazin & 1,220 & $4 \%$ \\
\hline desethylterbutylazin & 0,971 & $3 \%$ \\
\hline desisopropylatrazin & 1,337 & $5 \%$ \\
\hline isoproturon & 1,199 & $7 \%$ \\
\hline metolachlor & 0,964 & $5 \%$ \\
\hline propyzamide & 1,047 & $6 \%$ \\
\hline simazin & 0,918 & $4 \%$ \\
\hline terbuthylazin & 0,973 & $4 \%$ \\
\hline azoxystrobine & 0,586 & $7 \%$ \\
\hline metalaxyl & 0,658 & $6 \%$ \\
\hline penconazole & 0,568 & $4 \%$ \\
\hline & & \\
\hline
\end{tabular}


Table 3 Sampling rates of pesticides determined in the flow-through experiment

\begin{tabular}{|c|c|c|c|c|c|}
\hline Compounds & logKow & $\begin{array}{c}\text { Rs }\left(\mathrm{mL} \mathrm{day}^{-1} \mathrm{~g}^{-1}\right) \\
(\mathrm{n}=3)\end{array}$ & $\begin{array}{c}\text { Rs }(\mathrm{mL} \text { day } \\
1)(\mathrm{n}=3)\end{array}$ & $\begin{array}{c}\text { Correlation } \\
\text { coefficient } \\
\left(\mathrm{r}^{2}\right)\end{array}$ \\
\hline DIA & 1,2 & 339,4 & 67,9 & 12 & 0,9221 \\
\hline DEA & 1,5 & 664,7 & 132,9 & 14 & 0,7924 \\
\hline Simazine & 2,2 & 1088,6 & 217,7 & 15 & 0,8377 \\
\hline DET & 2,3 & 1268,5 & 253,7 & 14 & 0,8404 \\
\hline Atrazine & 2,7 & 1269,1 & 253,8 & 14 & 0,8588 \\
\hline Terbuthylazine & 3,2 & 816,3 & 163,3 & 14 & 0,8726 \\
\hline Acetochlor & 3 & 1115,7 & 223,1 & 9 & 0,9599 \\
\hline Metolachlor & 3,1 & 1341 & 268,2 & 14 & 0,8655 \\
\hline Alachlor & 3,5 & 1277,7 & 255,5 & 12 & 0,8572 \\
\hline Chlortoluron & 2,4 & 1257,4 & 251,5 & 12 & 0,876 \\
\hline Isoproturon & 2,5 & 1182,5 & 236,5 & 14 & 0,8378 \\
\hline Diuron & 2,7 & 1283,7 & 256,7 & 17 & 0,8092 \\
\hline Linuron & 3,2 & 702,5 & 140,5 & 14 & 0,9231 \\
\hline Metalaxyl & 1,7 & 1321 & 264,2 & 15 & 0,8497 \\
\hline Azoxystrobine & 2,5 & 768,8 & 153,8 & 14 & 0,9706 \\
\hline Propyzamide & 3,4 & 973,9 & 194,8 & 15 & 0,9038 \\
\hline Penconazole & 3,7 & 1394,8 & 279 & 8 & 0,9429 \\
\hline
\end{tabular}


Table 4 Comparison of our sampling rates $\left(R_{s}\right.$ in $\left.m L d a y-1\right)$ and previous studies using water renewal conditions

\begin{tabular}{|c|c|c|c|c|c|c|c|}
\hline Compounds & This study & $\begin{array}{l}\text { (Mazzella et } \\
\text { al. 2007) }\end{array}$ & $\begin{array}{c}\text { (Lissalde et al. } \\
\text { 2011) }\end{array}$ & $\begin{array}{l}\text { Hernando et } \\
\text { al, (2007) }\end{array}$ & $\begin{array}{c}\text { (Thomatou et al. } \\
\text { 2011) }\end{array}$ & $\begin{array}{c}\text { (Martínez } \\
\text { Bueno et al. } \\
\text { 2009) }\end{array}$ & $\begin{array}{c}\text { (Alvarez et al. } \\
\text { 2007a) }\end{array}$ \\
\hline $\begin{array}{l}\text { Experimental } \\
\text { set-up }\end{array}$ & $\begin{array}{c}\text { Tank with a } \\
\text { rotary } \\
\text { exposure } \\
\text { system }\end{array}$ & $\begin{array}{l}\text { Aquarium } \\
\text { for static } \\
\text { exposure }\end{array}$ & $\begin{array}{l}\text { Aquarium } \\
\text { for static } \\
\text { exposure }\end{array}$ & $\begin{array}{l}\text { Aquarium } \\
\text { for static } \\
\text { exposure }\end{array}$ & $\begin{array}{c}\text { Beaker } \\
\text { under stirring } \\
\text { conditions }\end{array}$ & $\begin{array}{c}\text { Beaker } \\
\text { under stirring } \\
\text { conditions }\end{array}$ & $\begin{array}{c}\text { Beaker } \\
\text { under stirring } \\
\text { conditions }\end{array}$ \\
\hline $\begin{array}{c}\text { Type of water and } \\
\text { sampler }\end{array}$ & $\begin{array}{c}\text { Tap water } \\
\text { pharm-POCIS }\end{array}$ & $\begin{array}{c}\text { Tap water } \\
\text { pharm- } \\
\text { POCIS }\end{array}$ & $\begin{array}{c}\text { Tap water } \\
\text { pharm-POCIS }\end{array}$ & $\begin{array}{c}\text { Sea water } \\
\text { pharm-POCIS }\end{array}$ & $\begin{array}{l}\text { Lake water pest- } \\
\text { POCIS }\end{array}$ & $\begin{array}{c}\text { Sea water } \\
\text { pharm-POCIS }\end{array}$ & $\begin{array}{c}\text { Water quality } \\
\text { not specified } \\
\text { pest-POCIS }\end{array}$ \\
\hline Atrazine & 253.8 & 239 & 228 & 192 & 245 & 214 & - \\
\hline DEA & 132.9 & 121.5 & 173 & 146 & 162 & - & - \\
\hline DET & 253.7 & 205 & 213 & - & - & - & - \\
\hline Simazine & 217.7 & 210.3 & 199 & 239 & 178 & 223 & - \\
\hline DIA & 67.9 & 63.6 & 176 & - & - & - & - \\
\hline Acetochlor & 223.1 & 225.2 & 241 & - & - & - & - \\
\hline Diuron & 256.7 & 247.3 & 199 & 256 & - & 86 & 45 \\
\hline Isoproturon & 236.5 & 217.6 & 167 & - & - & - & 86 \\
\hline Alachlor & 255.5 & - & 205 & 247 & 230 & - & - \\
\hline Metolachlor & 268.2 & - & 182 & 232 & 230 & - & - \\
\hline Azoxystrobin & 153.8 & - & 179 & - & - & - & - \\
\hline Propyzamide & 194.8 & - & - & - & - & - & - \\
\hline Terbuthylazine & 163.3 & 250.7 & 238 & - & - & - & - \\
\hline Linuron & 140.5 & 235.9 & 204 & - & - & - & - \\
\hline
\end{tabular}



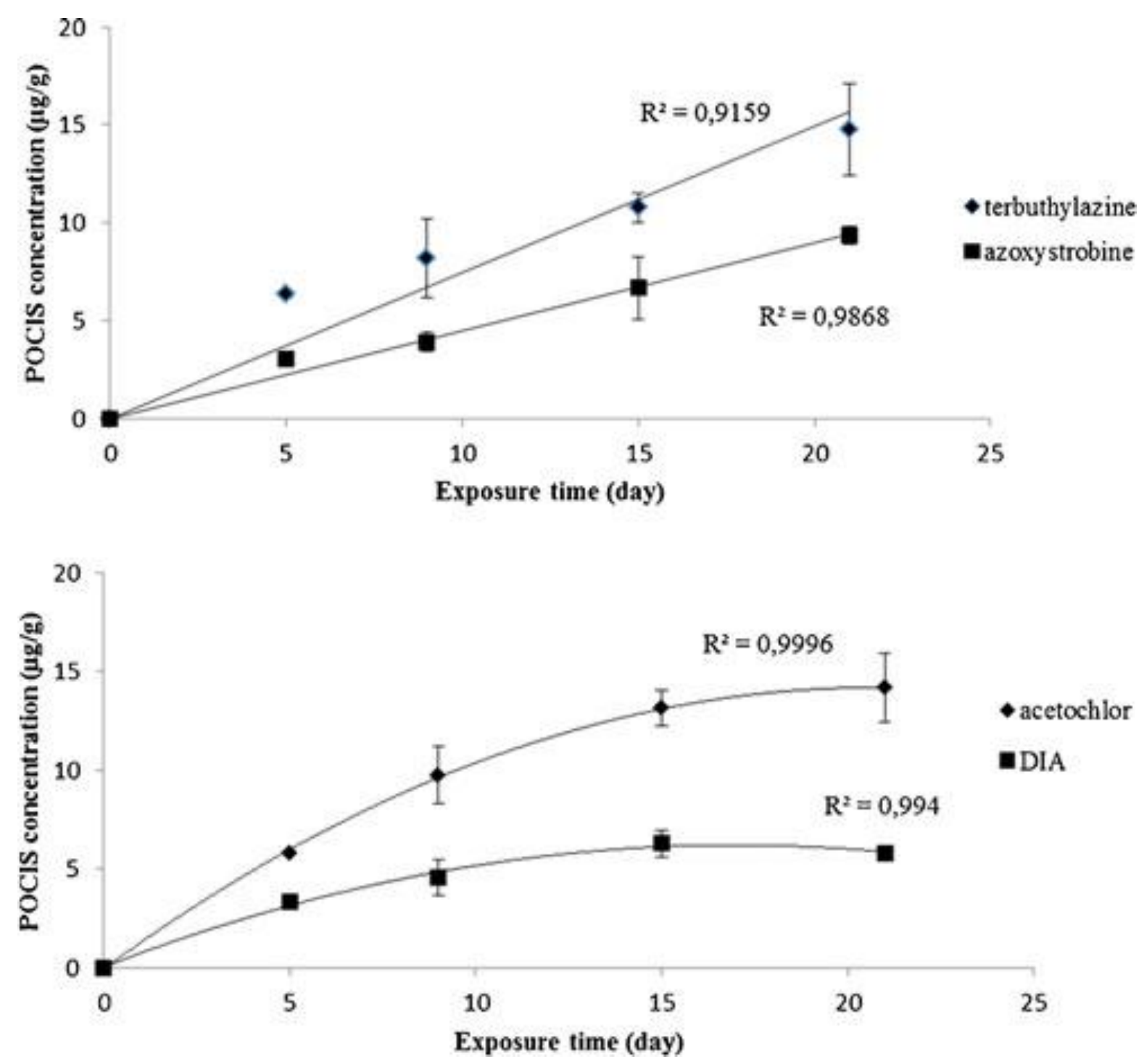

Fig 1. Some examples of pesticides uptake by POCIS over a period of 21 days exposure 


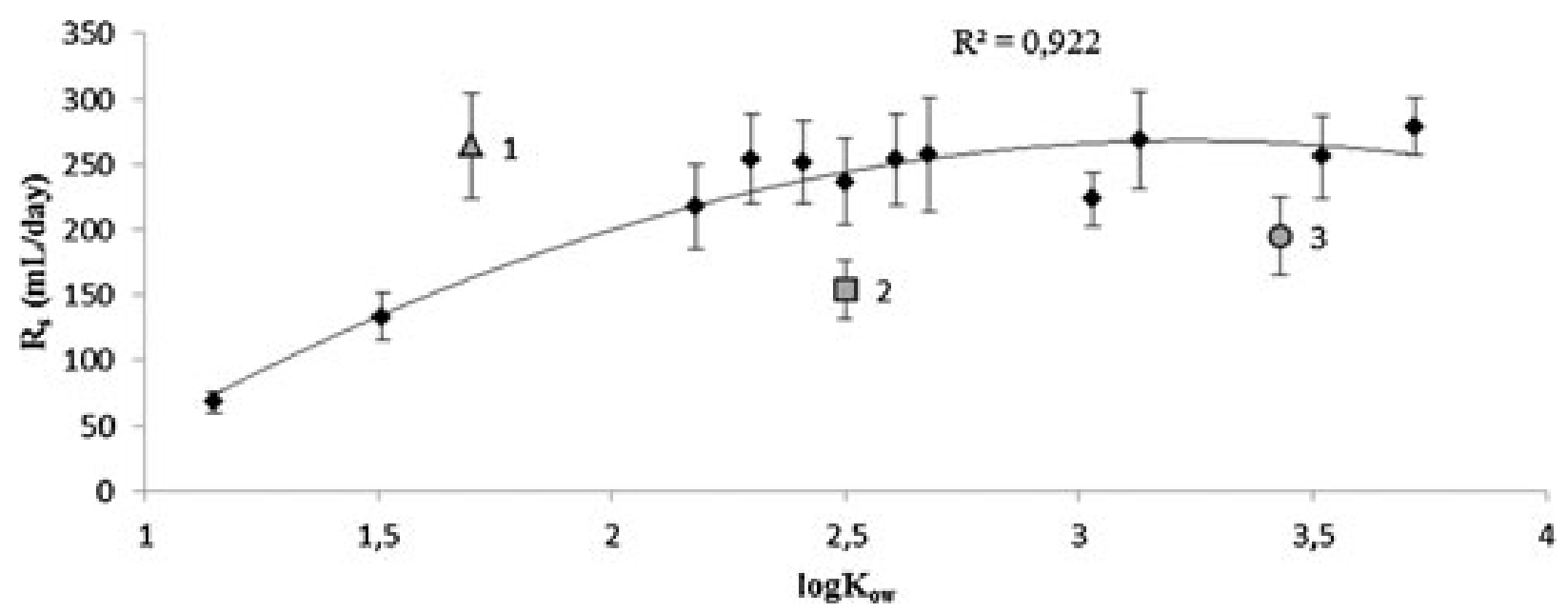

Fig 2 Relationship between sampling rates (Rs) and logKow. Metalaxyl (1), azoxystrobine (2), and propyzamide (3)

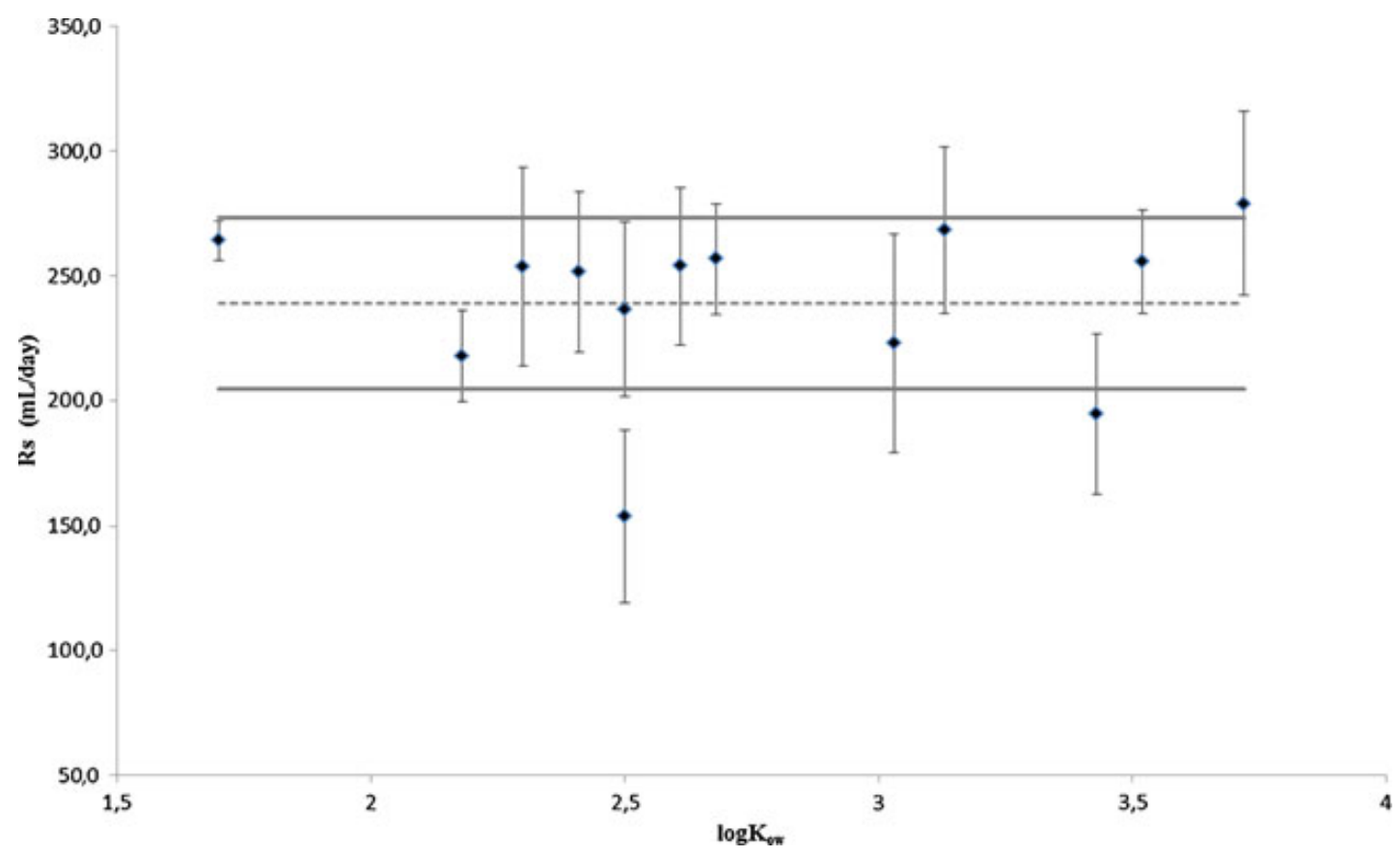

Figure 3 Average sampling rate of POCIS for pesticides whose polarity varies from 1.7 to 3.7. Discontinuous line of the figure represents the mean Rs value. Continuous lines represent the $20 \%$ of RSD calculated from the 13 Rs values 